\title{
CAPITAL FLOWS IN INDONESIA: THE BEHAVIOR, THE ROLE, AND ITS OPTIMALITY USES FOR THE ECONOMY
}

\author{
Fiskara Indawan, Sri Fitriani, Meily Ika Permata dan Indriani Karlina'
}

\begin{abstract}
The abundance of global liquidity post the global crisis resulted in a huge amount of international capital flows to Government Securities (GS) market. Besides useful, the flow of foreign capital potentially give a risk reversal that may leads to instability in domestic financial market. This paper analyzes the determinant of foreign investors including the risk and returns, both from domestic (pull factor) as well as from global (push factor). The result shows that the push factor was instrumentally influence the behavior of foreign investors in the GS (Government Securities) market. For long-term investors, their behavior to place their funds in GS market is influenced by push factor, but not significantly affected by the pull factor. However, for short-term investors, both pull and push factors influence their investment decisions. In addition simulation results indicate that in the future, the prospect of foreign investors in the securities market still faces challenges, particularly from the relatively high volatility as a result of the shock sensitivity of foreign investors on shock that can happen in the uncertainty in the international financial markets due to ongoing debt crisis resolution in developed countries. Concerning these findings, Bank Indonesia and the government needs to maintain and manage the returns and risks of domestic investment on a more competitive and relatively low level by maintaining the strength and resilience of the domestic economy and financial stability.
\end{abstract}

Keywords : Foreign Exchange, International Lending, Corporate Finance.

JEL Classification : F31, F34, G3

1 Economic Researcher in Grup Riset Ekonomi (BRE, Economic Research and Monetary Policy Department (DKM), Bank Indonesia. Ideas in this paper represent the writer's points of view and do not represent ideas or points of view of either DKM or Bank Indonesia. Email: indawan@bi.go.id, sfitriani@bi.go.id, meily@bi.go.id, indriani k@bi.go.id. 


\section{INTRODUCTION}

The abundance of global liquidity post-global crisis that resulted in a flood of international capital flows in the form of investment portfolio into Indonesia will provide a challenge for monetary policy implementation². Indonesia, like other emerging market countries, has a stronger level of economic growth and higher interest rates, while in the other hand, at the same time developed countries apply extra loosening monetary policy with relatively low interest rates. Both of these factors play an important role in the shifting of international capital flows to emerging markets that have a better rate of return and are supported by economic performance and improving risk (IMF, 2010).

In the one hand, the entry of the foreign capital showed increasing international confidence in economic fundamentals reinforced by the increase of Indonesia's rating to investment grade. Capital flow can increase domestic liquidity and can be used as an alternative investment funding source that is relatively cheaper and can encourage investment activity and encourage the domestic economy.

However, besides being useful, in the other hand, international capital flow has high potential risk if it is not managed wisely. Massive capital inflow leads to appreciation of the exchange rate and is able to weaken the competitiveness of exports. Besides, it can lead to higher risks of economic overheating on the economy and increasing pressure on inflation along with the sharp increase in asset prices as well as credit growth and investment that tend to be more expansive. At the same time, the global economic condition that is still vulnerable as well as uncertain international financial markets along with debt crisis in Europe could trigger the fluctuation in international financial markets and lead to high risk of instability in domestic financial markets and the exchange rate in the case of reversal of capital in short time (sudden reversal), especially for the short-term capital flow.

Thus, the foreign capital flow is expected to be managed properly in order to give optimal benefits to economic as well as can be minimized the risks. In order to minimize the potential risk in the management of international capital flow, it needs a better understanding about the patterns of capital inflow behavior in financial markets especially in Government Securities (SUN) market along with increasing foreign ownership in the market. In-depth analysis includes several factors, which are the risk factors and the returns that can be derived from domestic (pull factor) or from global (push factor), that affect foreign investors when they decide to make the purchase and sale in Government Securities (SUN) market ${ }^{3}$. The analysis also needs to be focused to get a good understanding about the characteristics of investor with investment time

2 Some emerging markets facing massive capital inflow has taken several policies beyond interest rate policy in managing capital inflows as macro prudential policy and capital controls (IMF, 2011). Ostry (2010) argued that the policy mix in the face of capital inflows depends on the country's economic conditions, the level of foreign exchange reserves, quality of prudential rule, strengthening exchange rate and persistence of capital inflows.

3 Analyses using high-frequency (daily data) 
horizon (long-term and short-term). The results of this study are expected to give appropriate policy recommendations in managing capital inflow, especially in financial markets.

The purposes of this study are to identify the foreign investors' behavior in the Government Securities (SUN) market, both long-term and short-term investors as either in aggregate or individually, especially their net transaction (purchases minus sales) in secondary market of Government Securities (SUN). The analysis of behavior identification includes the factors that affect investors' motivations which are returns factors and risk factors, whether it is sourced from domestic (pull factors) or from global (push factors); second, to simulate the prospect of foreign investors in the Government Securities (SUN) market by using the estimated model; and third, to recommend the aspects needed to be considered in the management of international capital flow based on the findings in two purposes of this study.

\section{THEORY}

\subsection{Modern Portfolio Theory (MPT)}

Modern Portfolio Theory (MPT) or Portfolio Theory is a mathematical formulation of the diversification concept in investment, with the aim to investment assets collection selection that gives the most efficient composition either in terms of return or risk. MPT is a financial theory that attempts to establish the composition or proportions of a wide selection of assets in order to maximize the expected return of portfolio for a certain level of risk, or instead to minimize risk for a level of expected return. This theory was first introduced by Harry Markowitz (1952) and developed by James Tobin (1958) by adding an asset that is risk-free into the analysis.

If investors, especially foreign investors, have two risky investment portfolio options which is investment in Indonesian financial market that have return $R_{D}$ and variance $\sigma_{D}^{2}$ and in international financial market with return $R_{F}$ and variance $\sigma_{F}^{2}$ investors can invest their funds with the proportion by $\omega_{p}$ for asset in Indonesian financial markets and by $1-\omega_{p}$ for asset in international financial market, then expected return portfolio and risk of the portfolio are:

$$
\begin{aligned}
& R_{P}=\omega_{P} R_{D}+\left(1-\omega_{P}\right) R_{F} \\
& \sigma_{P}^{2}=E\left(R_{P}-E R_{P}\right)^{2}=\omega_{P}^{2} \sigma_{D}^{2}+2 \omega_{P}\left(1-\omega_{P}\right) \rho \sigma_{D} \sigma_{F}+\left(1-\omega_{P}\right)^{2} \sigma_{F}^{2}
\end{aligned}
$$

where $\sigma_{P}^{2}$ is the standard deviation of $R_{D}$ and $R_{F^{\prime}}$ and $\rho$ is the correlation between $R_{D}$ and $R_{F}$.

In portfolio theory that used mean-variance model, investor will choose the efficient investment portfolio (efficient portfolio) which has a high return and low risk. In Figure 1, the combinations of all efficient portfolios are in BB curve where the investment risk $\sigma_{P}^{2}$ is getting small on each return investment $R p$. 


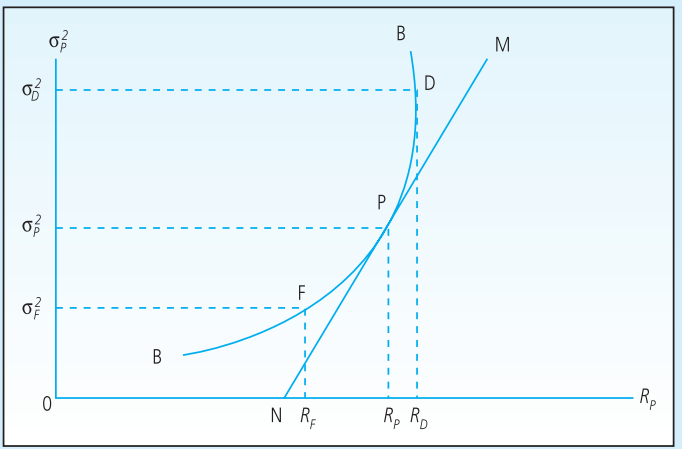

Figure 1.

Efficient Portfolio

In order to know the optimal portfolio allocation between domestic and foreign investment then it is using capital market line MN that is a combination of return and risk from risky and free risk asset. The slope in equilibrium will touch BB curve at the point $P$, which is portfolio combination that has return $R_{P}$ and level of risk $\sigma_{P}^{2}$. If investors want to gain higher return then they should add their investment portfolio in risky asset as well as having a higher risk so that it moves towards point $\mathrm{M}$. Instead, investors will gain lower return when they have less risky investment so that it moves towards point $\mathrm{N}$.

The number of optimal investment $\omega_{P}^{*}$ is obtained from substitution equation (1) and (2) into the slope $\sigma_{P}^{2} /(R p-N)$ and slope $\left(\partial \sigma_{P}^{2} / \partial \omega_{\mathrm{p}}\right) /\left(\partial R_{P} / \partial \omega_{\mathrm{p}}\right)$ as used by Miller (1971), so that obtain:

$$
\omega_{P}^{*}=\frac{\left(\sigma_{F}^{2} R+K\right)}{(L+K R)}=f\left(R, \sigma_{D}^{2}, \sigma_{F}^{2}\right)
$$

Where

$$
\begin{array}{r}
R=\frac{\left(R_{D}-R_{F}\right)}{\left(R_{P}-N\right)}(3 \mathrm{a}) \\
K=\sigma_{F}^{2}-\rho \sigma_{D} \sigma_{F} \\
L=\sigma_{D}^{2}+\sigma_{F}^{2}-2 \rho \sigma_{D} \sigma_{F}
\end{array}
$$

\subsection{Long-term vs. short-term Investors}

Long-term and short-term investors differ in terms of investment period. Using portfolio theory with mean-variance analysis, Campbell and Viceira (2001) suggested that the short-term investors are facing the following one-period wealth maximization problem: 


$$
\max E_{t} W_{t+1}^{1-\gamma} /(1-\gamma)
$$

Where

$$
\log E_{t} W_{t+1}^{1-\gamma}=(1-\gamma) E_{t} w_{t+1}+\frac{1}{2}(1-\gamma)^{2} \sigma_{w t}^{2}
$$

subject to

$$
\begin{aligned}
& W_{t+1}=\left(1+R_{P, t+1}\right) W_{t} \\
& R_{P, t+1}=\alpha_{t} R_{t+1}+\left(1-\alpha_{t}\right) R_{R F, t+1}
\end{aligned}
$$

where $R_{p, t+1}$ is portfolio return, $R_{t+1}$ is return of risky assets, $R_{R F, t+1}$ is return of risk-free assets, $\alpha t$ is share of the portfolio placed on risky assets, and $\gamma$ is coefficient of relative risk aversion.

Furthermore, substituting equation (6) to (5) and then (4a) and (4), we obtain the maximization problem for the short-term investors as follows:

$$
\max \log E_{t}\left(1+R_{P, t+1}\right)-\frac{1}{2} \gamma \sigma_{p t}^{2}
$$

From equation (7), the short-term investors will achieve maximum wealth by maximizing their portfolio return and minimizing their risk (variance) portfolio. Optimal return and variance portfolio are

$$
\begin{aligned}
& r_{P, t+1}-r_{r f, t+1}=\alpha_{t}\left(r_{t+1}-r_{r f, t+1}\right)+\frac{1}{2} \alpha_{t}\left(1-\alpha_{t}\right) \sigma_{t}^{2} \\
& \sigma_{p, t}^{2}=\alpha_{t}^{2} \sigma_{t}^{2}
\end{aligned}
$$

Meanwhile, the long-term investors face wealth maximization problem for $\mathrm{K}$ period ahead, with the following budget constraint:

$$
W_{t+K}=\left(1+R_{P K, t+K}\right) W_{t}
$$

The maximization problem for the long-term investor is:

$$
\max \log E_{t}\left(1+R_{P, t+K}\right)-\frac{1}{2} \gamma \sigma_{p t+K}^{2}
$$

and the optimal return and variance of the portfolio are:

$$
\begin{aligned}
& K\left(r_{P, t+1}-r_{r f, t+1}\right)=\alpha_{t} K\left(r_{t+1}-r_{r f, t+1}\right)+\frac{1}{2} \alpha_{t}\left(1-\alpha_{t}\right) K \sigma_{t}^{2} \\
& \sigma_{p, t+K}^{2}=\alpha_{t}^{2} K \sigma_{t}^{2}
\end{aligned}
$$

By comparing equations (8) and (9) with (12) and (13), the return and variance portfolio of short-term investors are still optimal for the long-term investors. The mean and the variance of the short-term investors are equal to the long-term investor, multiplied by the factor of $\mathrm{K}$ period. 


\subsection{Determinants of Capital Flow}

The capital inflow to developing countries is driven by several factors. The high degree of financial integration accompanied by the rapid development of technology, especially information and communications technologies play important role in accelerating the increasing mobility of the capital flows. Besides, the development of capital market infrastructure accompanied by the liberalization of capital markets such as the elimination of barriers to repatriate, the reduction of barriers for foreign participation and ownership also contribute to the expansion of the capital flows to developing countries' markets.

There are two major determinants for capital inflow (Agenor, 2004; Calvo et al, 1994):

1. Internal or pull factors, which are linked to domestic policies, such as high productivity levels and growth rates, strong macroeconomic fundamentals, macroeconomic stabilization, structural reforms (for instance the capital liberalization and reduction of fiscal deficit), which would normally be compensated and reflected in the increase of a country's rating.

2. External or push factors such as (1) the low level of world interest rates, particularly in the U.S. and some other developing countries, which lead to the declining of risk premium, while give higher yield in emerging markets (2) recession or slowing down of level growth in developing countries will lead to low return level and reduce profit opportunity, hence will lead to the transfer of capital from developing countries to emerging markets.

Based on type and risk, capital flows can be categorized as follows:

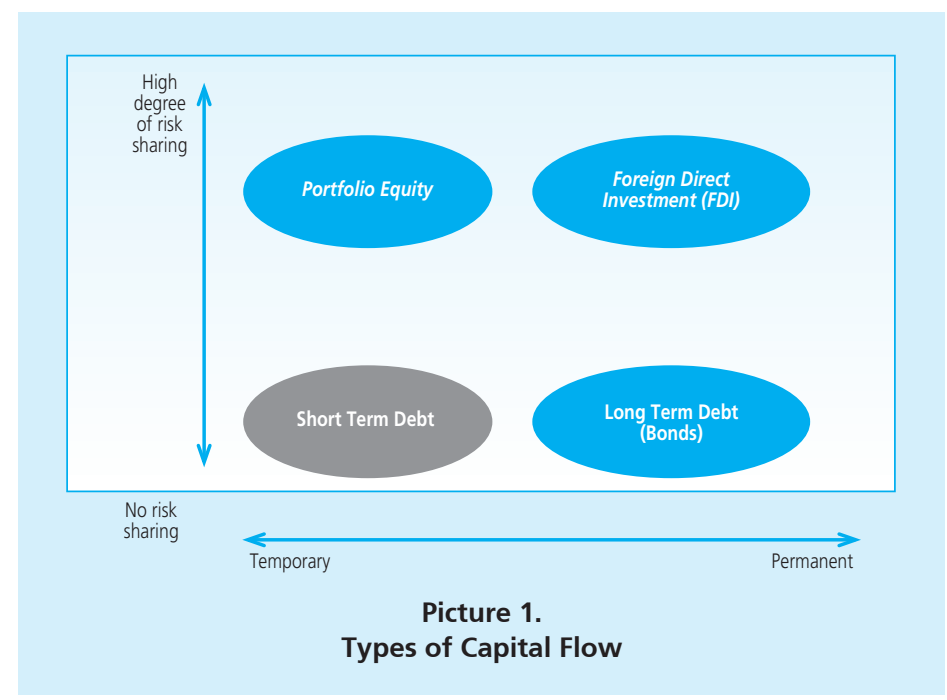

Larrain et al. (1997) found that long-term flows tend to be influenced by economic fundamentals, while short-term flows are influenced by the interest rate differential. Agung et al. (2011) by using Indonesian data and VAR models, found that the capital inflows into 
Indonesia are mainly caused by "push factors", especially from the impact of extra loosening monetary policies adopted by developing countries. In addition, we found that the inflows are particularly vulnerable to the reversal risk.

\subsection{Empirical Basis}

Several studies have analyzed the factors that led the flow of foreign capital flows into developing countries. There are few studies that specifically use VAR to analyze capital flows in emerging countries like Ying and Kim (2001), Vita and Kyaw (2007), Goldfajn and Minella (2005), and Culha (2006). In general, Culha (2006) and Fratzscher (2011) stated that the domestic factor (pull factors) is important factors in attracting capital flows in emerging countries. While Forbes and Warnock (2011) stated that factors from abroad (push factors) to be a driving force of capital flows to emerging countries.

Agung et al (2011) using OLS method with monthly data from January 2004 - December 2010 examines factors affecting capital flows in the stock market, SBI and Government Securities (SUN). He found the capital flows are positively influenced by two pull factors namely domestic economic growth (production index) and domestic interest rate changes, and three push factors namely the level of global risk (EMBIG), the global liquidity excess (money supply in the U.S.) and the changes in U.S. interest rates. Meanwhile, capital flows are negatively affected by U.S. economic growth. Furthermore, to examine the effect of capital flows on macroeconomic variables, he used the VAR method on quarterly data for the period of 1994 to 2010. The results were capital flows have a positive influence on foreign exchange reserves, money supply, and stock index, and negative effects on the real exchange rate (appreciation).

Nugroho (2010) examined the factors affecting capital flows that are proxied from the foreign exchange transactions with domestic banks from LHBU. Using OLS method and monthly data from January 2002 - March 2010, he found that the capital flows are positively influenced by two factors, which are spread between JIBOR domestic interest rate with LIBOR composite interest rate and economic growth in the U.S. (U.S. consumer confidence and U.S. production index), and was negatively influenced by exchange rate expectation (depreciation led to capital outflow).

Cadarajat (2008) by using ARDL method and quarterly data from 1985 to 2007 suggests that the capital flows proxied from FDI, FPI and other investment have positive effect on current account, domestic economic growth and the stock index and have negative effect on country risk and real interest rate.

In the financial markets (stocks and Government Securities (GS)) there are positive relationships between the price volatility and the trading volume. The higher the trading volume, the higher will the price volatility in the market. Karpoff (1987) stated that relationship between price volatility with trading volume can give a clearer view of the flow and dissemination of 
information in the market as well as its structure and its size. Positive relationship between two variables indicates that the market becomes more transparent because there are many investors who can obtain variety of information about market conditions and fundamentals from many sources.

\section{METHODOLOGY}

\subsection{Estimation Technique}

In a series of financial data, which is usually the high frequencies data, daily or weekly, is often found volatility clustering, where there is a period with high volatility while at different times, there were periods with low volatility. In the period of high volatility, a large shock (residual) tend to be followed by a large shock as well, instead, in periods of low volatility, a small shock will be followed by a little shock too.

Ordinary linear regression model emphasizes stable volatility assumptions (homoscedasticity). In the above case, where the homoscedasticity terms cannot be met, one can model the variance of $\varepsilon_{-} t$ as a function of the lag of error term. Modeling and forecasting the volatility gives several advantages such as a more efficient estimator if the problem of heteroscedasticity can be solved. Besides, since theforecast confidence interval can vary across time, the variance modeling of error term will help to give more accurate interval.

Engle (1982) introduced the concept of Autoregressive Conditional Heteroscedasticity $(\mathrm{ARCH})$. In this model, variance of error term in period $t$ is affected by the square of previous error term (volatility) in several periods.

$$
\sigma_{t}^{2} \equiv E\left\{\varepsilon_{t}^{2} \mid I_{t-1}\right\}=\omega+\alpha \varepsilon_{t-1}^{2}
$$

With $\omega \geq 0$ and $\alpha \geq 0$. The above model is the ARCH (1), with $l_{t-1}$ is a collection of information that includes $\varepsilon_{t-1}^{2}$ and all previous information. ARCH model (1) states that when large shock occurs in period $t-1$, then $\varepsilon_{t}^{2}$ tends to be large, as well as $\sigma_{t}^{2}$. In other words, there is a correlation between $\varepsilon_{t}^{2}$ and $\varepsilon_{t-1}^{2}$. Unconditional variance from $\varepsilon_{t}^{2}$ is:

$$
\sigma_{t}^{2} \equiv E\left\{\varepsilon_{t}^{2}\right\}=\omega+\alpha E\left\{\varepsilon_{t-1}^{2}\right\}
$$

The above equation has a stationary solution which is: $\sigma_{t}^{2}=\frac{\omega}{1-a}$, because $0 \leq \alpha \leq 1$. Keep in mind that unconditional variance does not depend on $t$.

ARCH model (1) can be expanded into ARCH (p) as follows:

$$
\sigma_{t}^{2}=\omega+\alpha_{1} \varepsilon_{t-1}^{2}+\alpha_{2} \varepsilon_{t-2}^{2}+\cdots+\alpha_{p} \varepsilon_{t-p}^{2}=\omega+\alpha(L) \varepsilon_{t-1}^{2}
$$

The improvement of $\mathrm{ARCH}$ model variations that are very useful is introduced by Bollerslev (1986), known as Generalized ARCH or GARCH. GARCH model (q, p) can be written as follows: 


$$
\sigma_{t}^{2}=\omega+\sum_{j=1}^{p} \alpha_{j} \varepsilon_{t-j}^{2}+\sum_{j=1}^{q} \beta_{j} \sigma_{t-j}^{2}
$$

Or

$$
\sigma_{t}^{2}=\omega+\alpha(L) \varepsilon_{t-j}^{2}+\beta(L) \sigma_{t-j}^{2}
$$

With $\omega \geq 0, \alpha \geq 0$ and $\beta \geq 0$. GARCH is a more compatible alternative to model the ARCH with higher order. By using GARCH method the selection of lag $\varepsilon_{t}$ can be minimized.

\subsection{Empirical Model}

To investigate the determinants of foreign investors on Government Securities (SUN), we use econometric models test for equation (24) using GARCH.

$$
\text { Posisi Net Transaksi Investor Asing }=\left(\sum_{k=1}^{m} \propto_{k} \text { PushFactor }_{k}\right)+\left(\sum_{k=1}^{n} \beta_{k} \text { PullFactor }_{k}\right)
$$

The dependent variable is the position or the accumulation of foreign investor transaction (non-residents), both long-term and short-term. Transactions that are analyzed is the position

\begin{tabular}{|c|c|c|c|}
\hline \multicolumn{4}{|c|}{$\begin{array}{c}\text { Table } 1 . \\
\text { Independent Variables }\end{array}$} \\
\hline Factor & Variable & Data Candidate & Category \\
\hline \multirow[t]{7}{*}{ Return } & \multirow[t]{2}{*}{$\mathbf{R}_{\mathbf{D}}($ Domestic return $)$} & Yield nominal SUN 5 yr (yield5) & Pull factor \\
\hline & & $\begin{array}{l}\text { Interest rate } / 5 \text {-years real yield of GS (rridn) = current } \\
\text { yield -yoy inflation }\end{array}$ & Pull factor \\
\hline & \multirow[t]{2}{*}{$\begin{array}{l}\mathbf{R}_{\mathbf{D}}-\mathbf{R}_{\mathbf{F}} \text { (interest rate } \\
\text { differential) }\end{array}$} & $\begin{array}{l}\text { Current Spread = 5-years current yield of GS - 5- } \\
\text { years US T-Note (spread2) }\end{array}$ & Pull factor \\
\hline & & $\begin{array}{l}\text { Real Spread = } 5 \text { yr real yield of GS (rridn)- 5-years } \\
\text { real yield (rrus) }\end{array}$ & Pull factor \\
\hline & \multirow[t]{3}{*}{$\mathbf{R}_{\mathbf{F}}$ (foreign return) } & Yield nominal US T-Bills 3 month (USTB) & Push factor \\
\hline & & Yield nominal US T-Notes 5 yr (UST5) & Push factor \\
\hline & & $\begin{array}{l}\text { Interest rate /real yield in } 5 \mathrm{yr} \text { (rrus) = current yield } \\
\text { UST } 5 \text { yr -yoy inflation }\end{array}$ & Push factor \\
\hline \multirow[t]{3}{*}{ Risk } & \multirow{3}{*}{$\sigma_{D}^{2}$ (domestic risk) } & PUAB ON interest rate (puab) *) & Pull factor \\
\hline & & Exchange rate of USD/Rp (kurs) & Pull factor \\
\hline & & Credit Default Swap 5 yr (CDS) & Pull factor \\
\hline \multirow[t]{3}{*}{ Risk } & \multirow[t]{3}{*}{$\sigma_{F}^{2}$ (foreign risk) } & VIX (vix) & Push factor \\
\hline & & TED (ted) & Push factor \\
\hline & & OIS US (oisus) & Push factor \\
\hline
\end{tabular}
of net inflow (purchases minus sales) for each long-term and short-term investors in aggregate or individually. While the candidate of independent variables are as follows: 
We use daily data from 2004 until the end of 2011. The source of foreign investor transactions data was obtained from Government Securities transactions in secondary market, obtained from BI-SSSS system (Bank Indonesia Script less Securities Settlement System). While independent variable data is obtained from Bloomberg.

In order to identify foreign investor group behavior, consisting of long-term and short-term investors in Government Securities (SUN) market, we regress the equation (24) with dependent variable of the net transaction (purchase transaction - selling transaction) and the combination from various variables in Table 2 as the independent variables for each group. Each equation contains 4 or 3 independent variables that represent indicators of the global risk and return or the domestic risk and return. Total equation used is 72 equations. From 72 equations, we selected one equation for all foreign investors both aggregately and individually. The selection of the equation is based on the number of significant independent variables.

\section{RESULT AND ANALYSIS}

\subsection{Stylized Fact of Government Securities (SUN)}

The transactions of foreign investors in Indonesia tend to increase. In 2011, foreign investors purchase transactions reached $44.7 \%$ from the total value of transactions in Indonesia Government Securities (SUN) market (Figure 4). Besides, looking at the net transaction (purchase transactions net minus sales), more foreign investors took selling position during 2006-2008, and recorded the building stock during 2009-2011 (Figure 5). In terms of ownership, as of June 2012, foreign investors have a market share of $27.40 \%$ (Figure 6).

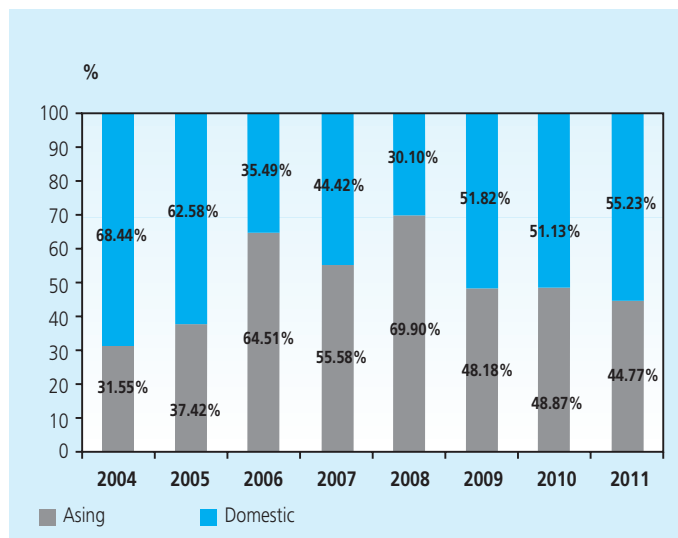

Figure 2. Foreign Transaction Value

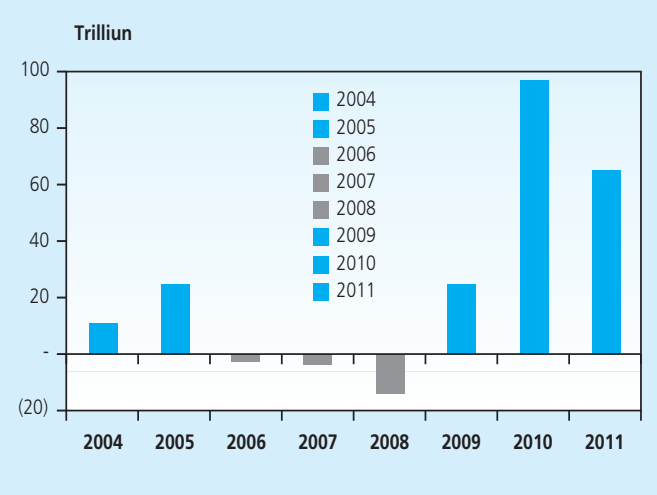

Figure 3. Net Position of Buy-Sell Foreign Investor 


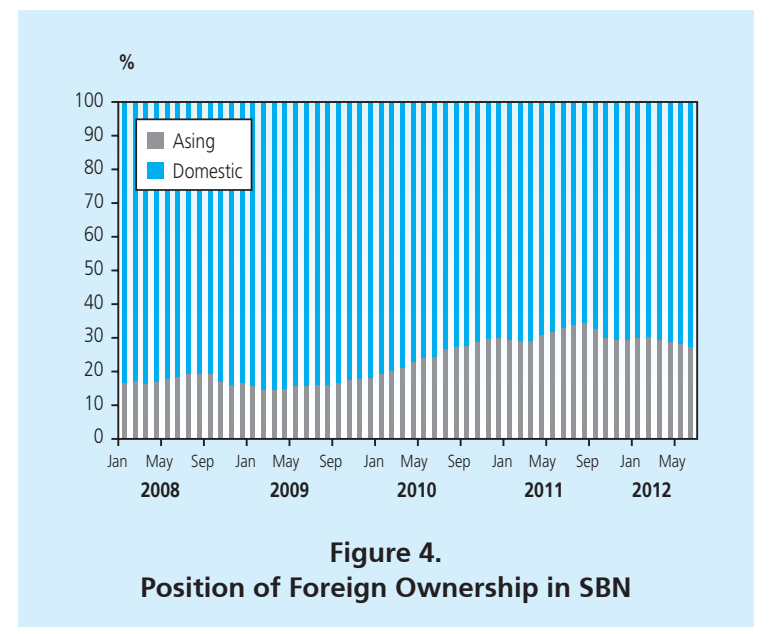

In order to categorize the long-term or the short-term investor, we use the Government Securities (SUN) trading in secondary market. Figure 7 shows that there are 7 most active foreign investors, with the average activity of buying - selling of $70 \%$ from the total transaction value of foreign players. As explained before, the difference between the long-term and the short-term investor is on their investment time horizon. In this paper, the long-term investor is defined as foreign institutional investors who have significantly increase their position in Government Securities since 2009, which was the starting period of rapid capital inflows into Government Securities (SUN) market. Instead, the short-term investors are foreign institutional investors that have no significant changes in their Government Securities (SUN) position for the same period. Based on these definitions, then in accordance with Table 4, the investors fall into the category of long-term investors are investors $A, B$ and $C$ and short-term investors are investors D, E, F and G.

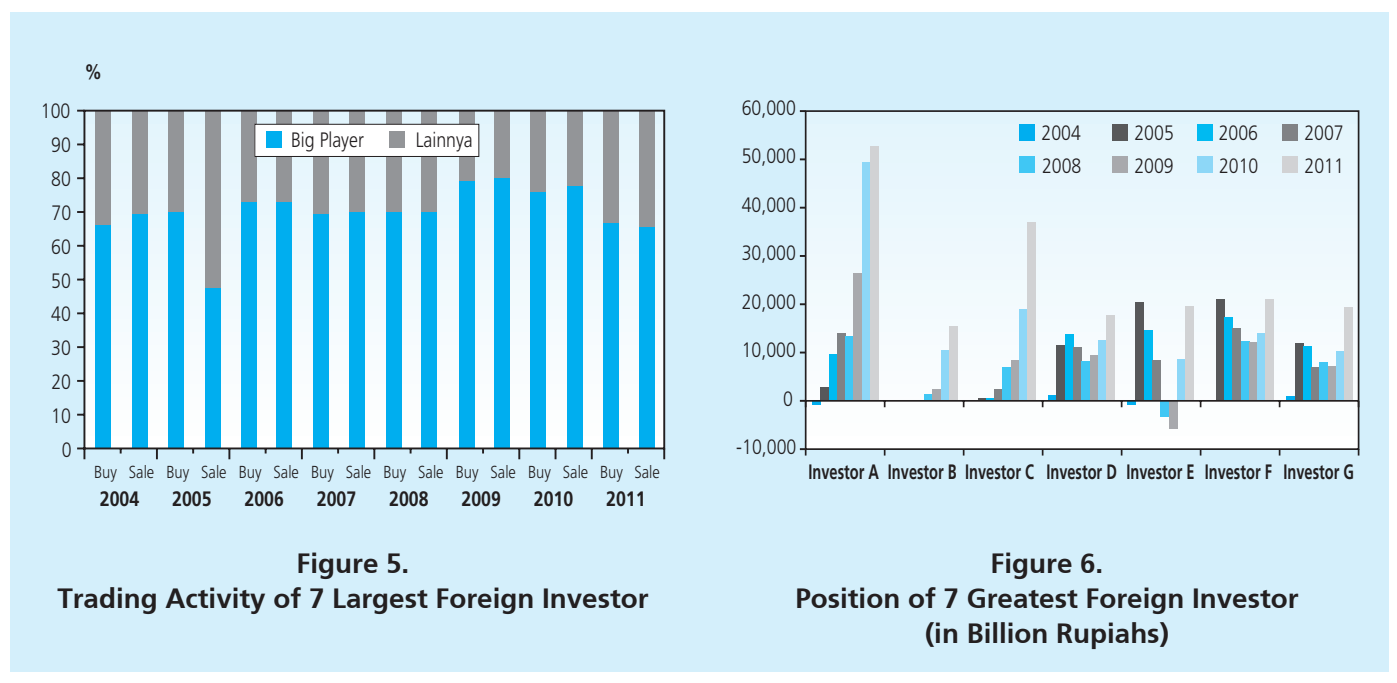




\begin{tabular}{c|c|c|c|c}
\multicolumn{7}{c}{ Table 2. } \\
\cline { 2 - 3 } & \multicolumn{2}{c}{ Position Changes of Greatest Foreign Investor } \\
\hline 1 & Investor & Mean 2004-2008 & Mean 2009-2011 & Changes \\
\hline 2 & A & 2,706 & 21,411 & $791.4 \%$ \\
\hline 3 & B & 1,439 & 9,442 & $656.0 \%$ \\
\hline 4 & C & 7,881 & 42,838 & $543.6 \%$ \\
\hline 5 & D & 7,901 & 12,432 & $157.4 \%$ \\
\hline 6 & E & 9,201 & 13,297 & $144.5 \%$ \\
\hline 7 & F & 13,232 & 15,756 & $119.1 \%$ \\
\hline
\end{tabular}

From table 4, in 2011 when there was rapid of capital inflows, the long-term and shortterm investors have relatively similar portion of 46:34 (Figure 10). This shows that both investors have relatively equal effect on Government Securities (SUN) market.

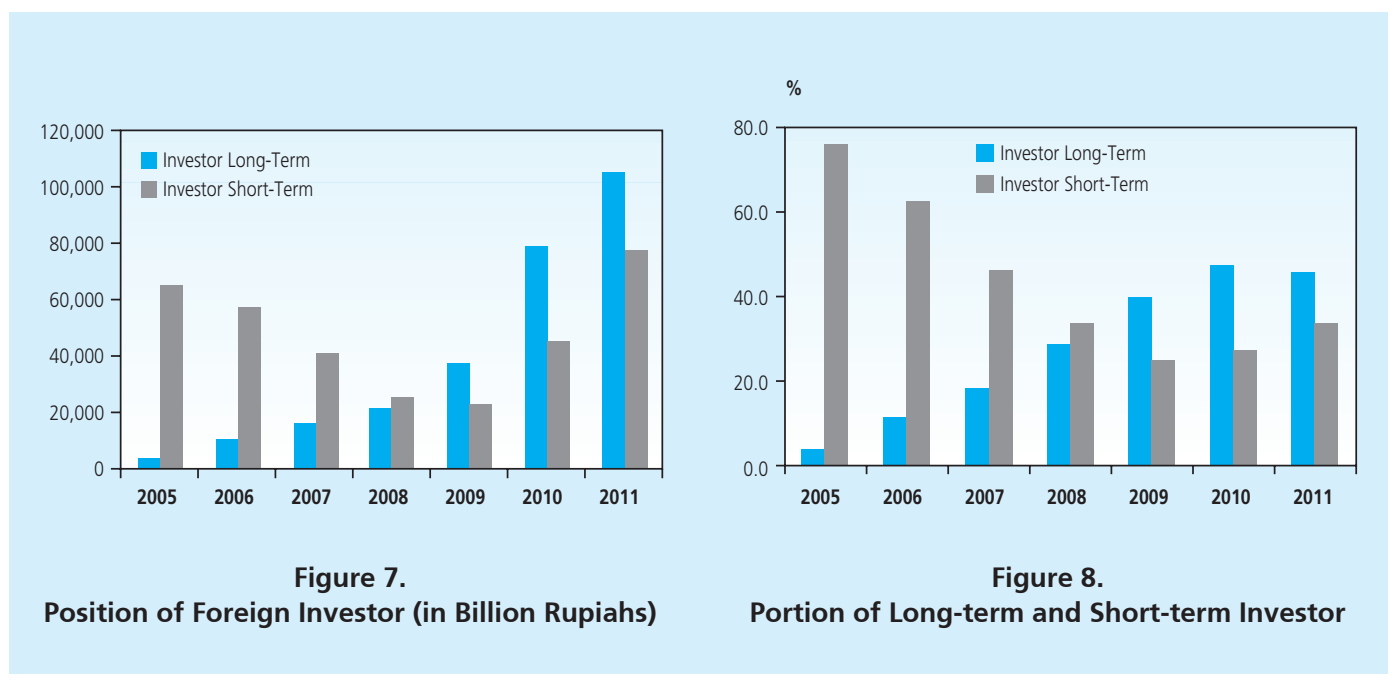

Long-term investors tend to be active after the global financial crisis (end of 2008). Meanwhile, the short-term investors have been actively trading in Indonesian Government Securities market, and its movement is very volatile, showing their higher motives for capital gain (indicated from a very high buying and selling activities ). 


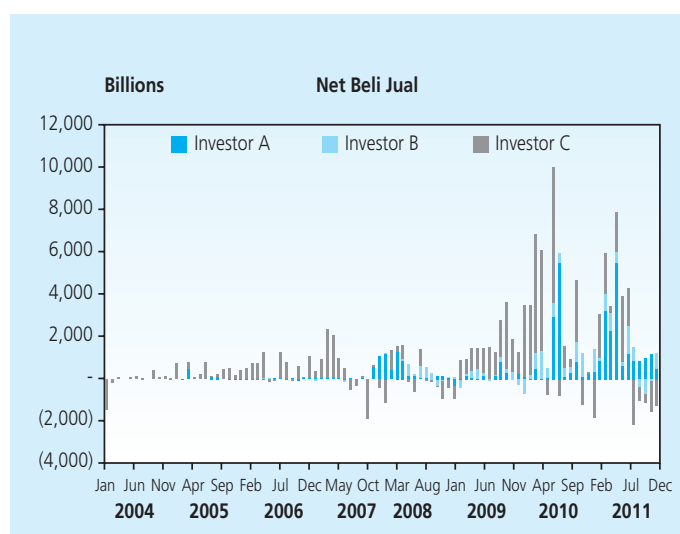

Figure 9.

Net Activity of Buy-Sell of Long-term Investor

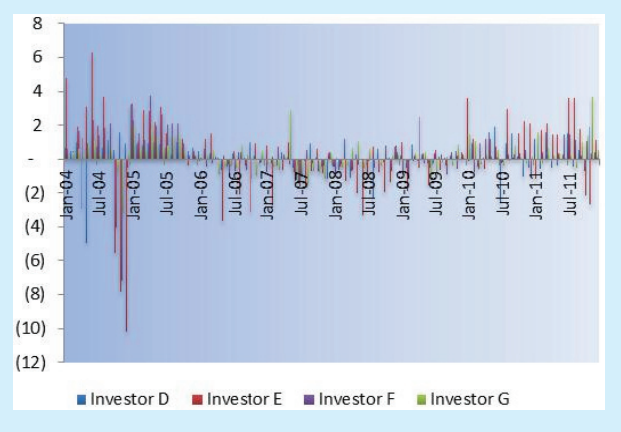

Figure 10.

Net Activity of Buy-Sell of Short-term Investor

\subsection{Estimation Result}

Regression results for 72 combinations using GARCH (Equation 19) obtained a general equation that can be used on all foreign investors both groups (long-term and short-term investors) as well as individual of foreign investors. The independent variable of the equation are the 5 -year yield as domestic return variables, the 5-year U.S. T Notes yield as foreign return variables, the interbank (PUAB ON) rates as domestic risk variables and the VIX index as foreign risk variable. Next, this general equation will be tested on all investors both group of investors (long-term and short-term).

\section{Long-Term Investor}

The result of estimated general equation for the long-term investor showed only push factors (global factors), both profit and risk, that significantly affect the behavior of investors in the Government Securities market. The test results remain consistent with the behavior of individual investors. From 3 long term investors tested, two individual investors perform the same behavior (Investor A and B). Meanwhile, the behavior of investor C transaction cannot be well explained by the variable yield5 (proxy for domestic return), USTB (proxy for global return), PUAB (proxy for domestic risk) and the VIX (global risk). Regression results show that considerable improvement of the long-term foreign investor position in the GS market, especially since the beginning of the global financial crisis in 2008 was driven by the push factors which represented from the low foreign interest rates and the relatively high foreign risk. Foreign investors are looking for the alternative placement of investment with relatively high interest rate and low level of risk.

The huge push factor shows the vulnerability of the GS market to the risk of large sudden reversal of capital flows when the intensity of risk in the international financial markets increased 
sharply. Therefore, the government and Bank Indonesia need to continue the awareness of and to monitor the global financial markets developments and prepare the contingency plans to address these risks to minimize their impact on financial stability and domestic economy.

The results of impulse response in Figure 12 shows that the shock of a rise in 5 years U.S. T-Notes by 100 basis points would lead to lower position of long-term investors net transaction (or make net sales) by approximately Rp 11 billion at that time $(t=0)$ with the cumulative impact by Rp 14 billion. While the shock of a rise in VIX index by 100 basis points lead to long-term investors sales by Rp 1.7 billion, with the cumulative impact by Rp 2.4 billion. The result ofindividual impulse response (Investor A and B) shows higher sensitivity. In Figure 13, the increase shock of 100 basis points U.S. T-Notes yields lead to investors A and B to make net sales by Rp 19 billion and similarly, the increase of 100 basis points VIX index lead to net sales by $\mathrm{Rp} 2$ billion at the time $\mathrm{t}=0$.
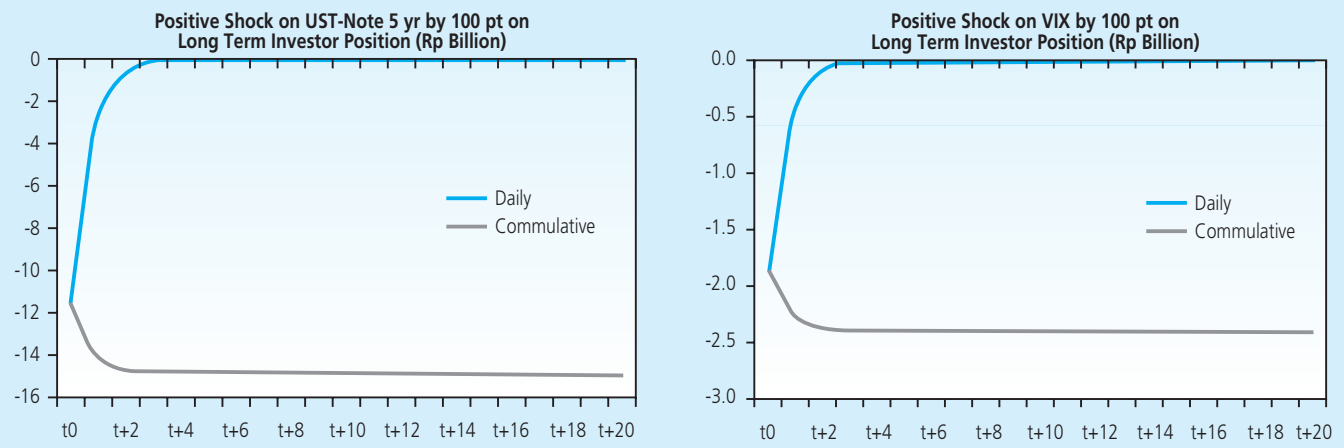

Figure 11.

Impulse Response Function Result to Long Term Investor (in Billion Rupiahs)
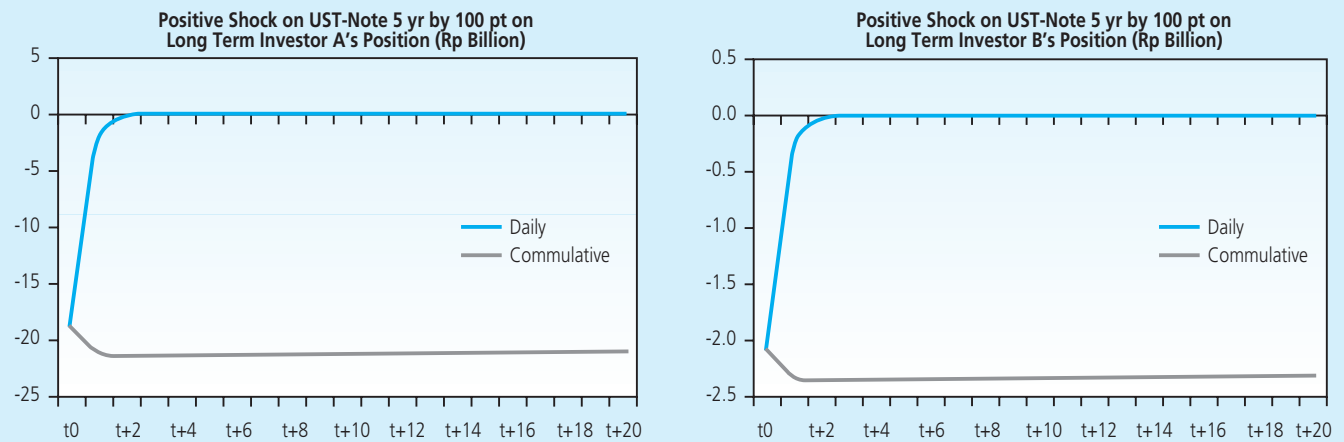

Figure 12.

Impulse Response Function Result to Investor A and B / Long-Term (in Billion Rupiahs) 

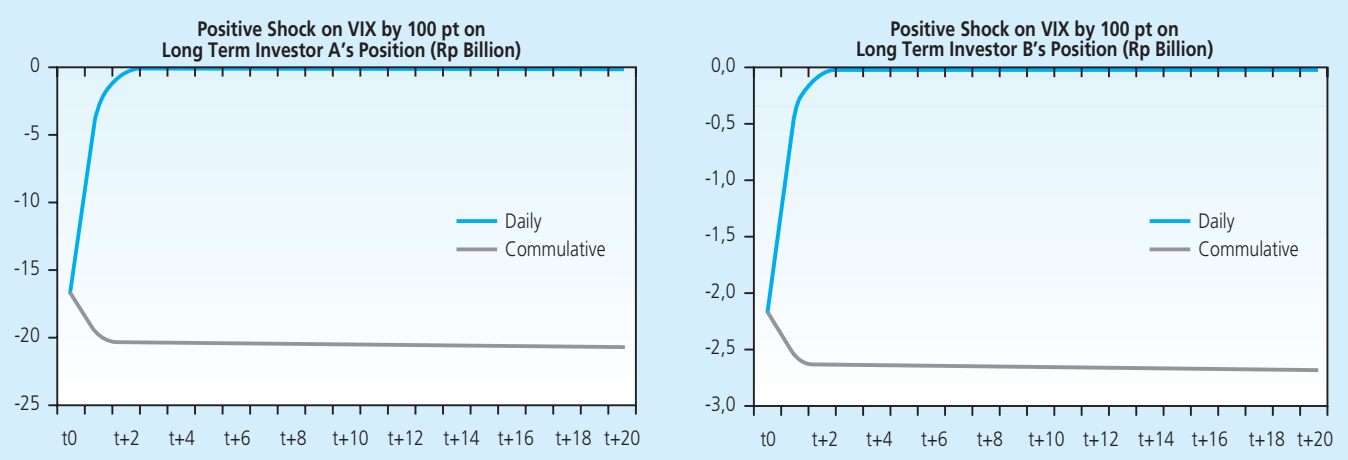

Figure 12.

Impulse Response Function Result to Investor A and B / Long-Term (in Billion Rupiahs) Lanjutan

\section{Short-term Investor}

In contrast to long-term investors, short-term investor transaction behavior is influenced by both push factors and pull factors (domestic factor) in the Government Securities (GS) market. The regression result suggests that the high frequency of short-term investor transactions in GS market is driven more sensitively on each of changes in the pull factors and the push factors. Both ofthese factors will affect the expected return and the risk tolerance to accept. This is in line with the nature of short-term investor transactions that tend to only look at short-term profits through capital gains.

The high frequency of short-term investor transactions that is not accompanied by the increasing position will lead to high volatility in the GS markets, which in turn may affect the stability of the overall financial markets. Therefore, considering short-term investor transaction is very volatile, and then from domestic points of view, the government and Bank Indonesia need to consider the factors that influence the short-term investors by maintaining domestic economic condition such as maintaining domestic competitive interest rate and keeping the level of domestic risk at a fairly low level. Meanwhile, to encounter the risk of capital flows reversal, the government and Bank Indonesia need to continue their awareness on risks in the international financial market and prepare the contingency plans.

The results of the individual impulse response in Figure 14 shows that the increase shock Yield 5 by 100 basis points would lead the short-term investors to lower net transaction position (or making net sales) by Rp 25.5 billion at that time $(t=0)$ with the cumulative impact by $R p$ 31.05 billion. On the other hand, the increase shock on 100 basis points UST-5 Year Notes index will lead the short-term investors to net sell position by Rp 80.7 billion, with the cumulative impact by Rp 98.3 billion. Furthermore, the increasing shock on the interbank rate (PUAB ON) by 100 basis points lead the short-term investors to book net sales position by Rp 11.07 billion 
with cumulative impact by Rp 13.5 billion, while a 100 basis points increase on VIX index lead to net sales by $\mathrm{Rp} 7.07$ billion at the time $\mathrm{t}=0$ with the cumulative effect by $\mathrm{Rp} 8.6$ billion.
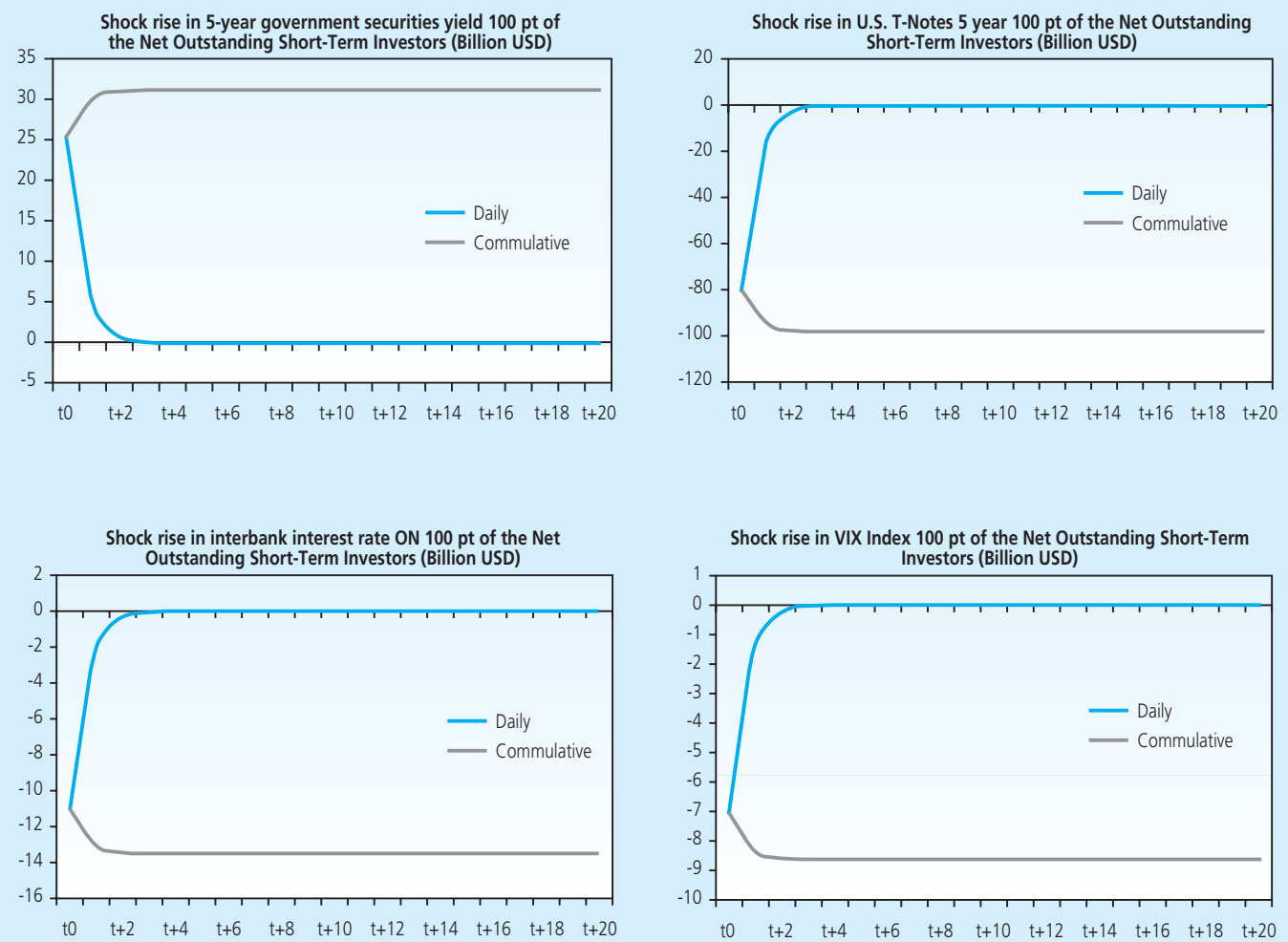

Figure 13.

Impulse Response Function Result to Position of Short-Term Investor (in Billion Rupiahs)

Although in general the results of the regression for the short term individual investors show similar to the group behavior, the push factor is more consistent than the pull factor. Variable of push factor (U.S. T-Notes and the VIX index) has a significant influence on all tested short-term individual investors (Figure 15 and Figure 16). Meanwhile, the returns of the domestic factors proxied by Yield-5 significantly affect only two over four short term individual investor (Investor F and G) and only one investor (Investor F) that is significantly influenced by the domestic risk proxied from PUAB variable. 



Figure 14.

Impulse Response Function Result to Position of Short-Term Investor D and E (in Billion Rp)
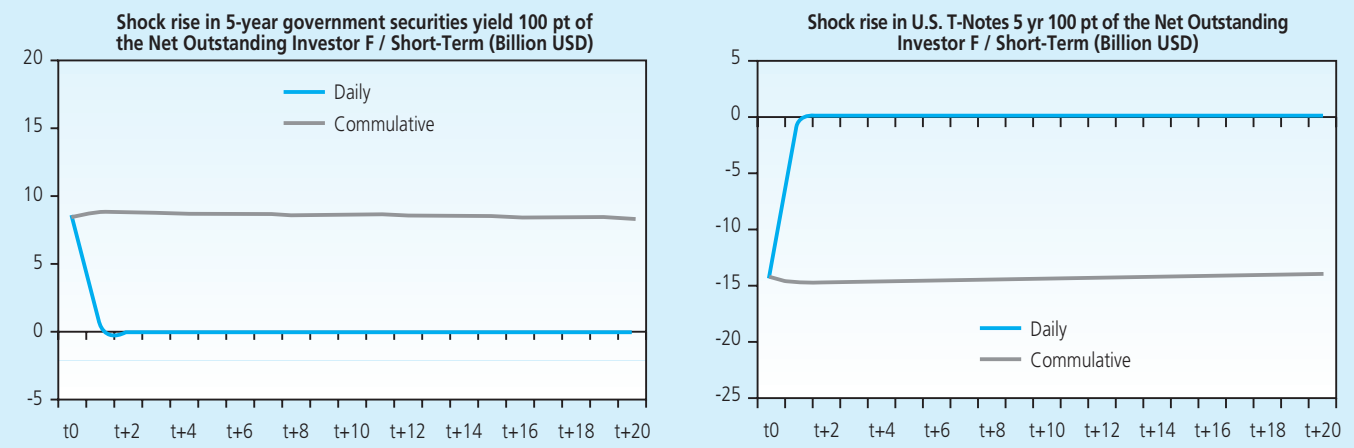

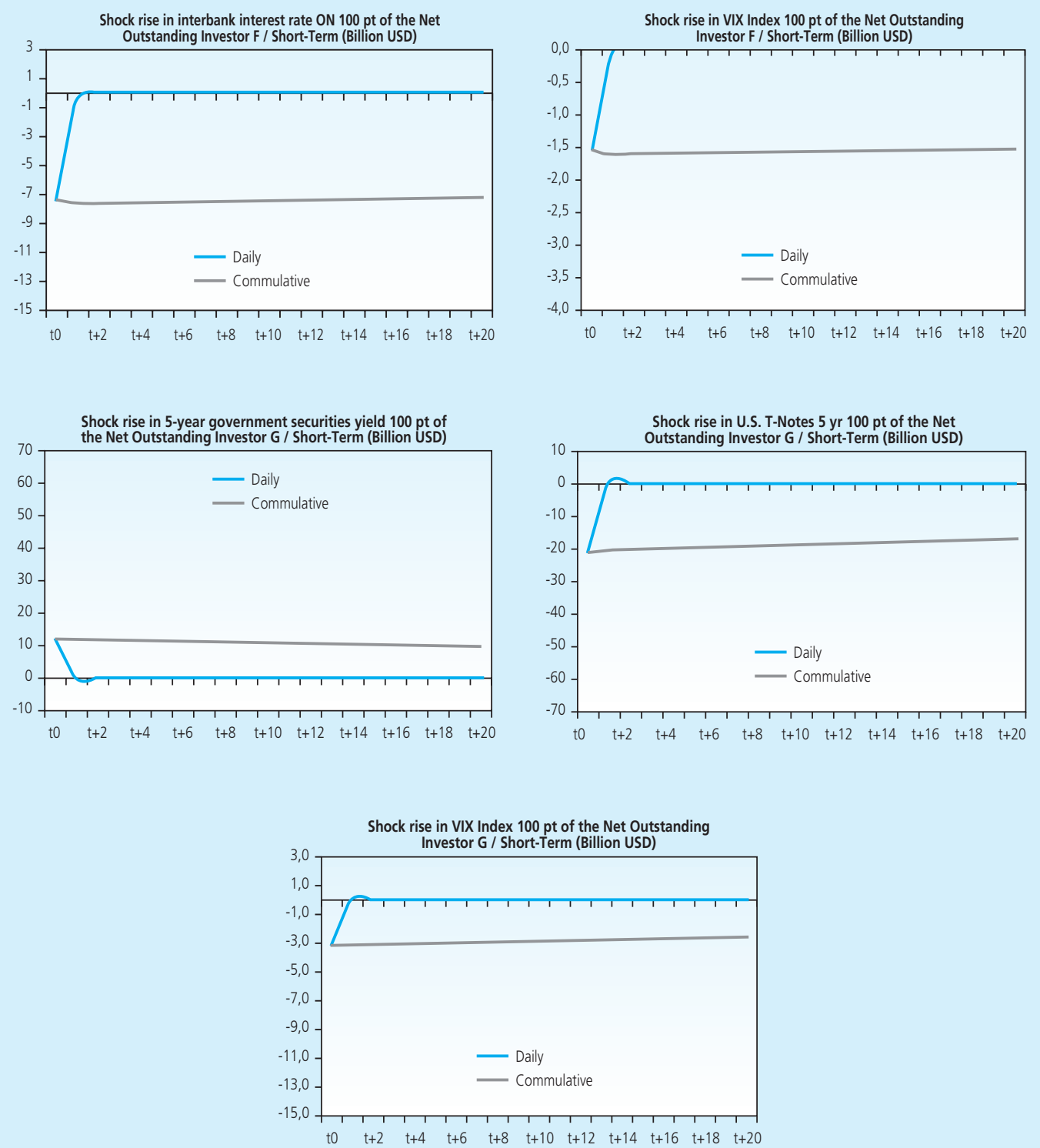

Figure 15.

Impulse Response Function Result to Position of Short-Term Investor F and G (in Billion Rp) 


\section{Prospect of Capital Flows}

In order to know the prospects of the capital flows, we run simulations using the above estimation both for the long-term and the short-term investors. The simulations use three scenarios; mild, moderate, and crises scenario ${ }^{4}$ with such criteria as outlined in Table 3. Determinations of the criteria are based on the historical patterns in each variable since 2004.

\begin{tabular}{l|l}
\multicolumn{2}{c}{ Table 3.} \\
Historical Pattern of Mild, Moderate, and Crisis Condition \\
\multicolumn{1}{c}{ Condition } & Daily Changes \\
\hline Mild & 1 Deviation Standard \\
\hline Moderate & 2 Deviation Standard \\
\hline Crisis & 4 Deviation Standard
\end{tabular}

Using these criteria, we can determine the daily shock value to use for the following variables. See Table 4. The simulation result is presented in Table 5.

\begin{tabular}{l|r|r|r}
\multicolumn{2}{c}{ Table 4. } \\
\multicolumn{1}{c}{ Daily Shock on 4 Variable (basis point) } \\
\multicolumn{1}{c|}{ Variable } & MILD & MODERATE & CRISIS \\
\hline ShockYield SUN 5 Yr & 19 & 38 & 76 \\
\hline Shock US T Notes 5 Yr & 7 & 14 & 28 \\
\hline Shock PUAB ON Rate & 124 & 248 & 496 \\
\hline Shock VIX Index & 198 & 396 & 791
\end{tabular}

\begin{tabular}{|c|c|c|c|c|c|c|}
\hline \multicolumn{7}{|c|}{$\begin{array}{l}\text { Table } 5 . \\
\text { Shock Effect on } 4 \text { Variables to Net Position of Foreign Investor Transaction (in Billion Rp) }\end{array}$} \\
\hline \multirow{2}{*}{ Investor } & \multicolumn{3}{|c|}{1 Day Shock (Billion Rp) } & \multicolumn{3}{|c|}{1 Month Permanent Shock (Billion Rp)) } \\
\hline & Mild & Moderate & Crisis & Mild & Moderate & Crisis \\
\hline LONG-TERM & -4.5 & -9.0 & -18.0 & -22.5 & -45.1 & -180.0 \\
\hline SHORT-TERM & -34.7 & -69.5 & -138.9 & -173.67 & -347.4 & $-1,390.1$ \\
\hline TOTAL & -39.2 & -78.5 & -157.0 & -196.2 & -392.5 & $-1,570.1$ \\
\hline
\end{tabular}

The simulation shows the short-term investors are more sensitive to the shock of the four explanatory variables. This is because the four explanatory variables can significantly influence the short-term investor decisions, while long-term investors are affected only by two push factors the U.S. T Notes and the VIX index. This result confirms that in the event of shock that causes changes in the four explanatory variables, the short-term investors react more quickly

4 Mild and Moderate $=$ shock for five consecutive days ( 1 week); Crisis = shock for 10 consecutive days (2 weeks). 
to respond the shock. In other words, in case of shock, the market became very volatile as a result of the short-term investors response.

Thus, amid the global financial markets that are still vulnerable due to the high uncertainty in the Euro area and the high U.S. government debt, the future prospects of the capital flows on GS market still faces challenges especially the market response on the upcoming shock. The high influence of the global factors in the GS market would lead to high volatility in the GS market. Foreign investor particularly the short-term investors will respond to the shock by making sales that may disrupt the stability of the overall financial markets and the stability in foreign exchange market, which in turn may affect the stability of exchange rate.

\section{v. CONCLUSION}

This paper provides several important empirical findings. First, the foreign investors in GS market are highly influenced by the global risk factor (push factors). The similar long-term and shortterm investors proportion (46:34) shows that the push factors reflected in the low 5 years yield US T Notes and global risk appetite (VIX), play an important role on their investment decision. Anytime the shock occurs in global financial market, the foreign investors will respond it by massive selling, which potentially disrupts the stability of domestic financial market and the exchange rate.

Second, in addition to the push factors, the behavior of the short-term investor is also influenced by pull factors (return and domestic risk), which are reflected with 5 years GS yield and interbank money market (PUAB ON) rate. The increase of GS yield will keep encouraging foreign capital inflow to GS domestic market, while the increase of PUAB ON interest rate will lead to the decrease of foreign capital inflow. The larger number of variables affecting the short-term investor transactions decision relative to the long term investor implies they are more reactive to respond the current shock.

The simulation result shows the prospect of foreign investors in GS market still have several challenges in the future, especially the vulnerability of the global financial market due to uncertainty. The strong effect of the push factor on foreign investor transactions shows that the GS market will remain face a relatively high volatility as the impact of foreign investors response on the upcoming shock, especially the short-term investors.

These conclusions, lead to some policy implication and recommendations; first, Bank Indonesia and the Government need to continue the effort to keep the domestic return to be more competitive and to manage the investment risk at relatively low, as well as keeping the sustainability of domestic economy, in order to keep the foreign investors place their investment on domestic financial market. Second, Bank Indonesia and the Government should cooperate in formulating a contingency plan to keep the stability of the GS market in the case of excessive volatility due to foreign investor responses, particularly in the worsening of global financial market condition. 


\section{REFERENCES}

Campbel JY and LM Viceira (2001). "Strategic Assets Allocation: Portfolio Choice for Long-term Investors," http://ciber.fuqua.duke.edu/ charvey/Teaching/BA453_2006/Campbell_Viceira. pdf

Chuhan, P, S. Claessens and N. Mamingi (1993). "Equity and Bond Flows to Asia and Latin America; The Role of Global and Country Factors," Policy Research, Working Papers, WPS 1160.

Culha, Ali Askin (2006), "A Structural VAR Analysis of the Determination of Capital Flow into Turkey," Central Bank Review, Central Bank of the Republic of Turkey.

Cuthbertson, K and D. Nitzsche (2005), "Quantitative Financial Economics: Stocks, Bonds and Foreign Exchange," John Wiley and Sons, Ltd, Second Edition.

Forbes, KJ. and FE. Warnock (2011). "Capital Flow Waves: Surges, Stops, Flight, and Retrenchment," National Bureau of Economic Research, Working Paper 17351, August 2011.

Fratzscher, Marcel (2011). "Capital Flows, Push Versul Pull factors and the Global Financial Crisis," National Bureau of Economic Research, Working Paper 17357, August 2011.

Goldfajn, Ilan and A. Minella (2005), "Capital Flows and Controls in Brazil: What have we learned?", National Bureau of Economic Research, Working Paper 11640, September 2005.

Gyntelberg J, M. Loretan, T. Subhani, and E. Chan (2009) "International portfolio rebalancing and exchange rate fuctuations in Thailand," BIS Working Papers No. 287.

Kaminsky, G. and S. Schumukler (2002), "Emerging market Instability: Do Sovereign Ratings Affect Country Risk and Stock Returns?" The World Bank Economic Review, Vol. 16, No. 2, pp 171-195.

Miller, NC and N. Whitman (1970). "A Mean-Variance Analysis of United States Long-term Portfolio Foreign Investment," The Quarterly Journal of Economics, Vol. 84, No. 2 (May, 1970), pp. 175-196

Ostry, JD et al (2011), "Managing Capital Inflows: What Tools to Use? IMF Staff Discussion Note, April 2011. 
IMF (2011), "Recent Experiences in Managing Capital Inflows-Cross-Cutting Themes and Possible Policy Framework," Prepared by the Strategy, Policy, and Review Department.

Vita, Glauco De and KS Kyaw (2007). "Determinants of Capital Flows to Developing Countries: A Structural VAR Analysis," Journal of Economic Studies, Vol. 35 No. 4. 2008, pp 304-322.

Ying, YH. and Y. Kim (2001). "An Empirical Analysis on Capital Flows: the Case of Korea and Mexico," Southern Economic Journal, April 2001; 67, 954-967.

Agung, Juda., Nugroho, M.N., Yanfitri. 2011. "Arus Modal Jangaka Pendek di Indonesia Pasca Krisis Global: Karakteristik, Prosepek, dan Respon Kebijakan". Working Paper Bank Indonesia.

Akitoby, B. dan T. Stratmann, 2006, "Fiscal policy and Financial Markets", IMF.

Boot, A. et al., 2005, "Credit Rating as Coordination Mechanism", Oxfords University Press. Cantor, R. dan F. Packer, 1996, "Determinants and Impact of Sovereign Credit Rating". FRBNY Economic policy Review/October 1996.

Cavallo, E., et al., 2008. "Do Credit Rating Agencies Add value? Evidence from the Sovereign Rating Business. Inter-American Development Bank.Edwards, S., 1985. "The Pricing of Bonds and Bank Loans in International Markets: An Empirical Analysis of Developing Countries' Foreign Borrowing", National Bureau of Economic Research.

Hartilius, K., K. Kashiwase. and L/E. Kodres (2008), "Emerging marketspread Compressions: Is it Real or is it Liquidity? IMF Working Paper 08/10

Jaramillo, L. dan C.M. Tejada, 2011, "Sovereign Credit Ratings and Spread in Emerging market: Does Investment grade Matter?", IMF.

Jeramillo, L., 2010, "Determinants of Investment grade Status in Emerging market", IMF.

Kaminsky, G. dan S. Schmukler, 2001. "Emerging markets Instability: Do Sovereign Rating Affect Country Risk and Stock Return?", World Bank.

Kiff, J. et al., 2012. "Are Rating Agencies Powerful? An Investigation into the Impact and Accuracy of Sovereign Ratings". IMF.

Lee, K., et al. , 2010. "Sovereign debt Rating Changes and Stock Liquidity around the World", Korea University Business School.

Powel, A. dan J.F. Martinez, 2008, "On Emerging Economy Sovereign Spreads and Rating". Inter-American Development Bank.

Rozada, M. G. dan E.L.Yeyati, 2011, "Risk Appetite and Emerging market Spreads". Universidad Torcuato Di Tella.

Rozada, M.G., 2005, "Global Factors and Emerging marketSpreads", Universidad Torcuato Di Tella. 


\section{APPENDIX}

\section{Dependent Variable: POSNET}

Method: ML - ARCH

Date: 08/07/12 Time: 12:06

Sample (adjusted): 31589

Included observations: 1587 after adjustments

Convergence achieved after 200 iterations

Presample variance: backcast $($ parameter $=0.7)$

$\mathrm{GARCH}=\mathrm{C}(8)+\mathrm{C}(9)^{*} \mathrm{RESID}(-1)^{\wedge} 2+\mathrm{C}(10)^{*} \mathrm{GARCH}(-1)$

\begin{tabular}{|c|c|c|c|c|}
\hline Variable & Coefficient & Std. Error & z-Statistic & Prob. \\
\hline C & 113.9447 & 25.58712 & 4.453207 & 0.0000 \\
\hline POSNET(-1) & 1.225203 & 0.020526 & 59.68938 & 0.0000 \\
\hline POSNET(-2) & -0.224816 & 0.020606 & 10.91041 & 0.0000 \\
\hline YIELD5 & -1.879022 & 2.237839 & -0.839659 & 0.4011 \\
\hline UST5 & -11.34816 & 5.689463 & -1.994592 & 0.0461 \\
\hline PUAB & 1.084902 & 1.497364 & 0.724541 & 0.4687 \\
\hline VIX & -1.846067 & 0.447188 & -4.128165 & 0.0000 \\
\hline \multicolumn{5}{|c|}{ Variance Equation } \\
\hline C & 112.1908 & 26.54838 & 4.225898 & 0.0000 \\
\hline $\operatorname{RESID}(-1)^{\wedge} 2$ & 0.065630 & 0.004167 & 15.74970 & 0.0000 \\
\hline GARCH(-1) & 0.942322 & 0.003231 & 291.6428 & 0.0000 \\
\hline R-squared & 0.999948 & Mean dependent var & & 34420.70 \\
\hline Adjusted R-squared & 0.999948 & S.D. dependent var & & 31564.77 \\
\hline S.E. of regression & 227.7380 & Akaike info criterion & & 13.30994 \\
\hline Sum squared resid & 81946030 & Schwarz criterion & & 13.34377 \\
\hline Log likelihood & -10551.44 & Hannan-Quinn criter. & & 13.32251 \\
\hline Durbin-Watson stat & 2.100886 & & & \\
\hline
\end{tabular}




\begin{tabular}{|c|c|c|c|c|}
\hline \multirow{2}{*}{\multicolumn{5}{|c|}{ Dependent Variable: $P$}} \\
\hline & & & \multicolumn{2}{|c|}{ Method: ML - ARCH } \\
\hline \multicolumn{5}{|c|}{ Date: $08 / 07 / 12$ Time: $12: 38$} \\
\hline \multicolumn{5}{|c|}{ Sample (adjusted): 171945} \\
\hline \multicolumn{5}{|c|}{ Included observations: 1929 after adjustments } \\
\hline \multicolumn{5}{|c|}{ Convergence achieved after 182 iterations } \\
\hline \multicolumn{5}{|c|}{ Presample variance: backcast $($ parameter $=0.7$ ) } \\
\hline \multicolumn{5}{|c|}{$\mathrm{GARCH}=\mathrm{C}(8)+\mathrm{C}(9)^{*} \mathrm{RESID}(-1)^{\wedge} 2+\mathrm{C}(10)^{*} \mathrm{GARCH}(-1)$} \\
\hline Variable & Coefficient & Std. Error & z-Statistic & Prob. \\
\hline C & 267.7758 & 63.92264 & 4.189061 & 0.0000 \\
\hline POSNET(-1) & 1.181177 & 0.021589 & 54.71125 & 0.0000 \\
\hline POSNET(-2) & -0.181296 & 0.021475 & -8.442287 & 0.0000 \\
\hline YIELD5 & 25.49576 & 7.244728 & 3.519216 & 0.0004 \\
\hline UST5 & -80.70680 & 15.62070 & -5.166659 & 0.0000 \\
\hline PUAB & -11.06977 & 5.938876 & -1.863951 & 0.0623 \\
\hline VIX & -7.074447 & 1.445532 & -4.894009 & 0.0000 \\
\hline \multicolumn{5}{|c|}{ Variance Equation } \\
\hline C & 2712.545 & 357.6632 & 7.584077 & 0.0000 \\
\hline $\operatorname{RESID}(-1)^{\wedge} 2$ & 0.045191 & 0.004001 & 11.29609 & 0.0000 \\
\hline GARCH(-1) & 0.946503 & 0.003923 & 241.2823 & 0.0000 \\
\hline R-squared & 0.999249 & Meandependentvar & & 40883.19 \\
\hline Adjusted R-squared & 0.999246 & S.D. dependent var & & 17901.91 \\
\hline S.E. of regression & 491.4292 & Akaike info criterion & & 15.10255 \\
\hline Sum squared resid & $4.64 \mathrm{E}+08$ & Schwarz criterion & & 15.13139 \\
\hline Log likelihood & -14556.41 & Hannan-Quinn criter. & & 15.11316 \\
\hline Durbin-Watson stat & 2.023039 & & & \\
\hline
\end{tabular}


Dependent Variable: POSNET_A

Method: ML - ARCH

Date: 08/03/12 Time: 15:17

Sample (adjusted): 31515

Included observations: 1513 after adjustments

Convergence achieved after 344 iterations

Presample variance: backcast (parameter $=0.7)$

$\mathrm{GARCH}=\mathrm{C}(8)+\mathrm{C}(9)^{*} \operatorname{RESID}(-1)^{\wedge} 2+\mathrm{C}(10)^{*} \mathrm{GARCH}(-1)$

\begin{tabular}{|c|c|c|c|c|}
\hline Variable & Coefficient & Std. Error & z-Statistic & Prob. \\
\hline C & 159.9976 & 53.96929 & 2.964604 & 0.0030 \\
\hline POSNET_A(-1) & 1.117612 & 0.021647 & 51.62911 & 0.0000 \\
\hline POSNET_A(-2) & -0.118524 & 0.021635 & -5.478300 & 0.0000 \\
\hline YIELD5 & -2.332061 & 3.515187 & -0.663424 & 0.5071 \\
\hline UST5 & -18.73924 & 7.558758 & -2.479143 & 0.0132 \\
\hline PUAB & 1.918756 & 1.580038 & 1.214373 & 0.2246 \\
\hline VIX & -2.083042 & 0.623298 & -3.341967 & 0.0008 \\
\hline \multicolumn{5}{|c|}{ Variance Equation } \\
\hline C & 57.43522 & 8.271893 & 6.943419 & 0.0000 \\
\hline $\operatorname{RESID}(-1)^{\wedge} 2$ & 0.012574 & 0.000940 & 13.37871 & 0.0000 \\
\hline GARCH(-1) & 0.987983 & 0.000872 & 1132.507 & 0.0000 \\
\hline R-squared & 0.999852 & Mean dependent var & & 23836.44 \\
\hline Adjusted R-squared & 0.999851 & S.D. dependent var & & 17590.30 \\
\hline S.E. of regression & 214.6835 & Akaike info criterion & & 13.31744 \\
\hline Sum squared resid & 69410069 & Schwarz criterion & & 13.35262 \\
\hline Log likelihood & -10064.65 & Hannan-Quinn criter. & & 13.33054 \\
\hline Durbin-Watson stat & 2.026375 & & & \\
\hline
\end{tabular}


Dependent Variable: POSNET_B

Method: $\mathrm{ML}-\mathrm{ARCH}$

Date: 08/03/12 Time: 15:04

Sample (adjusted): 3723

Included observations: 721 after adjustments

Convergence achieved after 465 iterations

Presample variance: backcast (parameter $=0.7$ )

$\mathrm{GARCH}=\mathrm{C}(8)+\mathrm{C}(9)^{\star} \mathrm{RESID}(-1)^{\wedge} 2+\mathrm{C}(10)^{*} \mathrm{GARCH}(-1)$

\begin{tabular}{|c|c|c|c|c|}
\hline Variable & Coefficient & Std. Error & z-Statistic & Prob. \\
\hline $\mathrm{C}$ & 54.51141 & 28.97710 & 1.881190 & 0.0599 \\
\hline POSNET_B(-1) & 1.176329 & 0.051550 & 22.81920 & 0.0000 \\
\hline POSNET_B(-2) & -0.175697 & 0.051447 & -3.415099 & 0.0006 \\
\hline YIELD5 & 3.520425 & 5.493664 & 0.640816 & 0.5216 \\
\hline UST5 & -16.72747 & 9.758567 & -1.714132 & 0.0865 \\
\hline PUAB & 3.709431 & 5.914948 & 0.627128 & 0.5306 \\
\hline VIX & -2.164078 & 0.527622 & -4.101572 & 0.0000 \\
\hline \multicolumn{5}{|c|}{ Variance Equation } \\
\hline C & 181.0126 & 33.29521 & 5.436596 & 0.0000 \\
\hline $\operatorname{RESID}(-1)^{\wedge} 2$ & 0.061301 & 0.006666 & 9.195631 & 0.0000 \\
\hline GARCH(-1) & 0.928537 & 0.009601 & 96.71625 & 0.0000 \\
\hline R-squared & 0.999740 & Mean dependent var & & 6627.379 \\
\hline Adjusted R-squared & 0.999737 & S.D. dependent var & & 5441.296 \\
\hline S.E. of regression & 88.17261 & Akaike info criterion & & 11.72626 \\
\hline Sum squared resid & 5550928. & Schwarz criterion & & 11.78980 \\
\hline Log likelihood & -4217.318 & Hannan-Quinn criter. & & 11.75079 \\
\hline Durbin-Watson stat & 2.168429 & & & \\
\hline
\end{tabular}


Dependent Variable: POSNET_C

Method: ML - ARCH

Date: 08/03/12 Time: 14:10

Sample (adjusted): 3611

Included observations: 609 after adjustments

Failure to improve Likelihood after 213 iterations

Presample variance: backcast (parameter $=0.7$ )

$\mathrm{GARCH}=\mathrm{C}(8)+\mathrm{C}(9)^{*} \mathrm{RESID}(-1)^{\wedge} 2+\mathrm{C}(10)^{*} \mathrm{GARCH}(-1)$

\begin{tabular}{|c|c|c|c|c|}
\hline Variable & Coefficient & Std. Error & z-Statistic & Prob. \\
\hline C & 12.55903 & 7.383175 & 1.701034 & 0.0889 \\
\hline POSNET_C(-1) & 1.347741 & 0.063468 & 21.23494 & 0.0000 \\
\hline POSNET_C(-2) & -0.345492 & 0.063317 & -5.456547 & 0.0000 \\
\hline YIELD5 & -0.737508 & 0.854343 & -0.863246 & 0.3880 \\
\hline UST5 & -0.495133 & 1.280885 & -0.386556 & 0.6991 \\
\hline PUAB & -0.466432 & 0.454711 & -1.025777 & 0.3050 \\
\hline VIX & 0.144641 & 0.222908 & 0.648883 & 0.5164 \\
\hline \multicolumn{5}{|c|}{ Variance Equation } \\
\hline C & 2.677693 & 3.106823 & 0.861875 & 0.3888 \\
\hline $\operatorname{RESID}(-1)^{\wedge} 2$ & 0.264474 & 0.035762 & 7.395345 & 0.0000 \\
\hline GARCH(-1) & 0.816807 & 0.019423 & 42.05455 & 0.0000 \\
\hline R-squared & 0.999886 & Mean dependent var & & 11325.22 \\
\hline Adjusted R-squared & 0.999885 & S.D. dependent var & & 11157.35 \\
\hline S.E. of regression & 119.6815 & Akaike info criterion & & 11.29132 \\
\hline Sum squared resid & 8622845. & Schwarz criterion & & 11.36377 \\
\hline Log likelihood & -3428.208 & Hannan-Quinn criter. & & 11.31950 \\
\hline Durbin-Watson stat & 1.868649 & & & \\
\hline
\end{tabular}


Dependent Variable: POSNET_D

Method: ML - ARCH

Date: 08/03/12 Time: 15:32

Sample (adjusted): 31688

Included observations: 1686 after adjustments

Convergence achieved after 342 iterations

Presample variance: backcast (parameter $=0.7$ )

$\mathrm{GARCH}=\mathrm{C}(8)+\mathrm{C}(9)^{*} \mathrm{RESID}(-1)^{\wedge} 2+\mathrm{C}(10)^{*} \mathrm{GARCH}(-1)$

\begin{tabular}{|c|c|c|c|c|}
\hline Variable & Coefficient & Std. Error & z-Statistic & Prob. \\
\hline C & 92.70394 & 23.56513 & 3.933945 & 0.0001 \\
\hline POSNET_D(-1) & 1.063743 & 0.026182 & 40.62836 & 0.0000 \\
\hline POSNET_D(-2) & -0.067759 & 0.026147 & -2.591516 & 0.0096 \\
\hline YIELD5 & 3.319171 & 2.214957 & 1.498526 & 0.1340 \\
\hline UST5 & -12.14377 & 4.811679 & -2.523812 & 0.0116 \\
\hline PUAB & 0.700817 & 1.475683 & 0.474910 & 0.6349 \\
\hline VIX & -1.671124 & 0.591787 & -2.823863 & 0.0047 \\
\hline \multicolumn{5}{|c|}{ Variance Equation } \\
\hline C & 54.08519 & 10.04509 & 5.384244 & 0.0000 \\
\hline $\operatorname{RESID}(-1)^{\wedge} 2$ & 0.030750 & 0.001705 & 18.03498 & 0.0000 \\
\hline GARCH(-1) & 0.972435 & 0.001556 & 625.1126 & 0.0000 \\
\hline R-squared & 0.995748 & Mean dependent var & & 11222.39 \\
\hline Adjusted R-squared & 0.995733 & S.D. dependent var & & 2777.218 \\
\hline S.E. of regression & 181.4111 & Akaike info criterion & & 12.91675 \\
\hline Sum squared resid & 55255876 & Schwarz criterion & & 12.94896 \\
\hline Log likelihood & -10878.82 & Hannan-Quinn criter. & & 12.92868 \\
\hline Durbin-Watson stat & 2.029965 & & & \\
\hline
\end{tabular}


Dependent Variable: POSNET_E

Method: ML - ARCH

Date: 08/03/12 Time: 15:38

Sample (adjusted): 31679

Included observations: 1677 after adjustments

Convergence achieved after 98 iterations

Presample variance: backcast (parameter $=0.7$ )

$\mathrm{GARCH}=\mathrm{C}(8)+\mathrm{C}(9)^{*} \mathrm{RESID}(-1)^{\wedge} 2+\mathrm{C}(10)^{*} \mathrm{GARCH}(-1)$

\begin{tabular}{|c|c|c|c|c|}
\hline Variable & Coefficient & Std. Error & z-Statistic & Prob. \\
\hline$C$ & 189.2419 & 36.57877 & 5.173546 & 0.0000 \\
\hline POSNET_E(-1) & 1.077573 & 0.024414 & 44.13708 & 0.0000 \\
\hline POSNET_E(-2) & -0.077229 & 0.024344 & -3.172443 & 0.0015 \\
\hline YIELD5 & 5.491383 & 4.269940 & 1.286056 & 0.1984 \\
\hline UST5 & -37.09031 & 9.909066 & -3.743069 & 0.0002 \\
\hline PUAB & -5.283109 & 3.799146 & -1.390604 & 0.1643 \\
\hline VIX & -3.488436 & 0.945942 & -3.687791 & 0.0002 \\
\hline \multicolumn{5}{|c|}{ Variance Equation } \\
\hline C & 783.2013 & 150.2073 & 5.214138 & 0.0000 \\
\hline $\operatorname{RESID}(-1)^{\wedge} 2$ & 0.036261 & 0.004220 & 8.592922 & 0.0000 \\
\hline GARCH(-1) & 0.955605 & 0.005294 & 180.5000 & 0.0000 \\
\hline R-squared & 0.998968 & Mean dependent var & & 8069.767 \\
\hline Adjusted R-squared & 0.998964 & S.D. dependent var & & 9175.607 \\
\hline S.E. of regression & 295.2718 & Akaike info criterion & & 14.04298 \\
\hline Sum squared resid & $1.46 \mathrm{E}+08$ & Schwarz criterion & & 14.07532 \\
\hline Log likelihood & -11765.03 & Hannan-Quinn criter. & & 14.05496 \\
\hline Durbin-Watson stat & 1.989021 & & & \\
\hline
\end{tabular}


Dependent Variable: POSNET_F

Method: $\mathrm{ML}$ - ARCH

Date: 08/03/12 Time: 15:48

Sample (adjusted): 31688

Included observations: 1686 after adjustments

Convergence achieved after 125 iterations

Presample variance: backcast (parameter $=0.7$ )

$\mathrm{GARCH}=\mathrm{C}(8)+\mathrm{C}(9)^{\star} \mathrm{RESID}(-1)^{\wedge} 2+\mathrm{C}(10)^{\star} \mathrm{GARCH}(-1)$

\begin{tabular}{|c|c|c|c|c|}
\hline Variable & Coefficient & Std. Error & z-Statistic & Prob. \\
\hline $\mathrm{C}$ & 96.93787 & 29.00713 & 3.341864 & 0.0008 \\
\hline POSNET_F(-1) & 1.034479 & 0.034218 & 30.23195 & 0.0000 \\
\hline POSNET_F(-2) & -0.037215 & 0.034256 & -1.086378 & 0.2773 \\
\hline YIELD5 & 8.528477 & 3.021516 & 2.822582 & 0.0048 \\
\hline UST5 & -14.31859 & 5.995188 & -2.388347 & 0.0169 \\
\hline PUAB & -7.352710 & 1.898121 & -3.873678 & 0.0001 \\
\hline VIX & -1.556119 & 0.650834 & -2.390961 & 0.0168 \\
\hline \multicolumn{5}{|c|}{ Variance Equation } \\
\hline $\mathrm{C}$ & 5936.775 & 549.5556 & 10.80287 & 0.0000 \\
\hline $\operatorname{RESID}(-1)^{\wedge} 2$ & 0.103559 & 0.010013 & 10.34206 & 0.0000 \\
\hline $\mathrm{GARCH}(-1)$ & 0.710128 & 0.024614 & 28.85108 & 0.0000 \\
\hline R-squared & 0.997706 & Mean dependent var & & 15001.01 \\
\hline Adjusted R-squared & 0.997698 & S.D. dependent var & & 3688.146 \\
\hline S.E. of regression & 176.9552 & Akaike info criterion & & 13.12920 \\
\hline Sum squared resid & 52574769 & Schwarz criterion & & 13.16141 \\
\hline Log likelihood & -11057.92 & Hannan-Quinn criter. & & 13.14113 \\
\hline Durbin-Watson stat & 2.007265 & & & \\
\hline
\end{tabular}


Dependent Variable: POSNET_G

Method: ML - ARCH

Date: 08/03/12 Time: 15:53

Sample (adjusted): 31670

Included observations: 1668 after adjustments

Convergence not achieved after 500 iterations

Presample variance: backcast (parameter $=0.7$ )

$\mathrm{GARCH}=\mathrm{C}(8)+\mathrm{C}(9)^{*} \mathrm{RESID}(-1)^{\wedge} 2+\mathrm{C}(10)^{*} \mathrm{GARCH}(-1)$

\begin{tabular}{|c|c|c|c|c|}
\hline Variable & Coefficient & Std. Error & z-Statistic & Prob. \\
\hline C & 113.0265 & 24.90232 & 4.538795 & 0.0000 \\
\hline POSNET_G(-1) & 0.966284 & 0.024542 & 39.37210 & 0.0000 \\
\hline POSNET_G (-2) & 0.023345 & 0.024728 & 0.944049 & 0.3451 \\
\hline YIELD5 & 12.25185 & 2.539103 & 4.825268 & 0.0000 \\
\hline UST5 & -20.93090 & 5.175821 & -4.043977 & 0.0001 \\
\hline PUAB & -0.492255 & 1.616411 & -0.304536 & 0.7607 \\
\hline VIX & -3.173168 & 0.512478 & -6.191808 & 0.0000 \\
\hline \multicolumn{5}{|c|}{ Variance Equation } \\
\hline C & 18657.47 & 421.8118 & 44.23174 & 0.0000 \\
\hline $\operatorname{RESID}(-1)^{\wedge} 2$ & 0.817660 & 0.052944 & 15.44399 & 0.0000 \\
\hline GARCH(-1) & 0.018109 & 0.011761 & 1.539728 & 0.1236 \\
\hline R-squared & 0.995271 & Mean dependent var & & 9755.743 \\
\hline Adjusted R-squared & 0.995254 & S.D. dependent var & & 2669.271 \\
\hline S.E. of regression & 183.8912 & Akaike info criterion & & 13.07786 \\
\hline Sum squared resid & 56168322 & Schwarz criterion & 13.11035 & \\
\hline Log likelihood & -10896.93 & Hannan-Quinn criter. & & 13.08990 \\
\hline Durbin-Watson stat & 1.963220 & & & \\
\hline
\end{tabular}


54 Bulletin of Monetary, Economics and Banking, January 2013

This page is intentionally left blank 